\title{
HISTERIA E FEMINILIDADE
}

André Michels

Psicanalistae Psiquiatra em Paris.

Tradução: Eloisa Araújo Ribeiro

Revi são da tradução: Angélica Bastose Gérard Grimberg
RESUMO: Discute-se a feminilidade nos dias de hoje a partir da abertura discursiva introduzida pelos estudos sobre a histeria, de Freud. A própria definição da clínica psicanalítica é remetida às modalidades de defesa contra a posição feminina e ao que ela veicula de diferença radical, aqui associada à castração. Mediante apresentação de uma "nota" clínica, aborda-se a feminilidade frente à inscrição e à relação dos sexos, evidenciando-se a função simbólica de uma mãe. A posição feminina na transmissão é tratada pelo viés da nomeação. A pesquisa clínica sobre a histeria indica que a posição feminina submetida à castração simbólica revela-se condição da flexão do nome e produção de diferença.

Palavras-chave: histeria, feminilidade, castração.

ABSTRACT: Histeria and femininity. The article discusses femininity in the contemporary world from the point of view of Freud's Studies on Histeria. The definition of the psychoanalytic clinical practice itself is referred to the modes of defense against the feminine position and the radical difference it imparts. The latter here is associated to castration. Using the presentation of a clinical "note", it approaches femininity in face of both inscription and sexual relations and highlights the symbolic function of the mother. The feminine position in transmission is treated through nomination. The clinical research on histeria indicates that the feminine position under symbolic castration reveals the conditions for the utterance of the name and for the production of difference.

Keywords: histeria, femininity, castration.

\section{PALAVRA DE MULHER}

Quem negaria, hoje em dia, que as relações entre homens e mulheres se transformaram profundamente há pelo menos um século? Quanto a determinar as razões e as causas, as análises divergem, algumas privilegiando os fatores econô- 
mico e social, outras considerando, antes, as implicações religiosas e, outras ainda se referindo a uma mudança da discursividade cujas raízes seriam bem mais antigas.

As lutas que desde meados do século passado tiveram por objeto a "causa das mulheres" visavam, a princípio, sua integração profissional, o direito de voto, a igualdade das chances, etc. Tais reivindicações só puderam vir à baila graças a uma transformação política ímpar, sendo a instauração de um regime democrático nos Estados Unidos da América e a Revolução Francesa apenas seus sinais anunciadores. Do ponto de vista da democracia, o Novo Mundo é, de fato, o mais antigo. Se os Estados U nidos de hoje ocupam o lugar que é o seu, é graças a suas instituições e ao funcionamento destas, tanto quanto ou até mesmo mais do que devido a seu peso econômico e militar. Se eles por acaso abusassem demais disso, como sempre tendem a fazer os poderosos do mundo, seria o prelúdio de seu declínio, como já ocorreu tantas vezes na história da humanidade. É surpreendente que seja nesse país que as mulheres tenham pela primeira vez adquirido o direito ao voto, em 1869, em um estado do Far West, o Wyoming, a leste do Grande Lago Salgado (é verdade que esse estado só se juntou à União em 1890). Também nesse país, departamentos de Women Studies foram organizados e desenvolvidos com resultados por vezes surpreendentes, mas nem sempre desprovidos de ranços ideológicos.

Foi nesse contexto da democratização - cujo movimento começou há mais de dois séculos e está longe de acabar — , portanto de uma relação diferente com a lei e com a autoridade ( política e religiosa), que um questionamento da posição tradicional da mulher em nossas sociedades ocidentais se tornou possível, sem correr grandes perigos. Estes eram bem reais, se considerarmos os procedimentos brutais e os métodos expeditivos empregados pela Inquisição na Europa, desde o século XIII. Embora ela tenha sido contrariada pouco a pouco pela centralização do poder real na França e pelo advento da Reforma em outros países, a Espanha seguiu um ritmo mais lento e continuou a enviar mulheres e homens para a fogueira, até o século das luzes; suprimida inicialmente em 1813, depois restabelecida por Ferdinando VII, a Inquisição só foi abolida definitivamente em 1834 (MORELLET, 1990; BENNASAR,1979). ${ }^{1}$ Daí para Wyoming, que passo! Isso nos dá uma pequena indicação sobre o tempo que as coisas levam para evoluir, as idéias novas para abrir caminho e os hábitos para mudar. Mesmo não sendo mais perseguidas e condenadas como bruxas, as mulheres não viam seu status mudar fundamentalmente; as instâncias política,

\footnotetext{
${ }^{1}$ Ver Morellet (1990) "Abrégé du Manuel des Inquisiteurs", 1762, que é o resumo em língua francesa do Directorium inquisitorum, redigido no século XIV por Nicolas Eymerich, Grande Inquisidor, com uma excelente introdução de J.-P. Guicciardi.
} 
jurídica e religiosa, as disposições mentais, sobretudo, que outrora as haviam julgado, não tinham desaparecido de um dia para o outro. Os discursos dominantes souberam se manter subjetivamente, quando não institucionalmente, por muito tempo além da extinção das últimas fogueiras da Inquisição. Considerando a história recente, não é proibido fazer a aproximação com as fogueiras ainda mais terríveis que inflamaram nosso século e incendiaram e ensangüentaram o Antigo Mundo, que vomitou sua alma nos campos de extermínio da Polônia.

Chegar até a eliminação física daquelas pessoas cujas únicas armas eram o sexo e a palavra, mostra bem a que ponto elas eram consideradas ameaçadoras para a ordem estabelecida e para os discursos em vigor. M esmo se no Ocidente as coisas tenham evoluído muito, sobretudo desde a Segunda Guerra M undial, o mesmo não aconteceu em outras regiões do globo. Entretanto, vale ainda perguntar por que foi preciso esperar a derrota nessa guerra para que as mulheres, enfim, obtivessem o direito de voto, na França e em outros países. 0 lugar dado às mulheres e ao feminino é sempre sintomático de uma estrutura social, discursiva ou subjetiva. 0 Ocidente, até nossos dias, não se esforçou para estudar o pensamento de uma excepcional riqueza sobre o status da mulher, elaborado na discussão dos sábios do Talmude, entre os séculos II eV de nossa era. Freud (1897/ 1986), por sua vez, não se enganou ao reconhecer nas bruxas de pios teólogos e de zelosos juristas o papel de ancestrais e precursoras das histéricas de doutos médicos, estabelecendo, além disso, um paralelo entre a sina reservada às mulheres e o lugar atribuído aos judeus nas sociedades ocidentais (FREUD, 1909/ 1941). Ele se deixou ser ensinado por essas "bocas de ouro" (LACAN, 1991) que foram suas primeiras pacientes, que não teriam tido direito à palavra em nenhum dos discursos tradicionais e que a medicina de seu tempo só estava pronta para acolher com reserva. Qualificá-las de histéricas, com efeito, não deixava de ter uma conotação pejorativa; 0 que obrigatoriamente não mudou desde então. Apesar de tudo, tal diagnóstico, tornado freudiano, mostra-se meIhor e às vezes até mesmo ostensivo. Para alguns, ele serve para designar a melhor estrutura possível (portanto relação do sujeito com o desejo) que há, para opô-la a estruturas menos nobres; outros tornaram-se verdadei ros militantes da histeria. Ponto de partida da psicanálise, ela parece também ter se tornado seu término; assim somos levados, no rastro de Lacan, a defini-la como uma histerização do discurso.

Ao término de um século de freudismo, temos o direito de nos perguntar se o termo histeria não serviu para várias gerações de psicanalistas para abordar de viés e às vezes de través a questão tão espinhosa da feminilidade, como se ela tivesse tido que tomar esse caminho desviado para se fazer ouvir. É verdade também que ela escaparia a uma abordagem por demais direta, assim como a 
toda tentativa de controle, conceitual ou não, já que nesse nível tudo é metáfora. Daí também a dificuldade para o historiador em localizar seus vestígios no passado, como observam Duby e Perrot (1991): ela foi relegada às margens da história, onde só irrompia acidentalmente, e passa através das redes da historiografia clássica, ligada, antes, aos fatos de guerra, aos atos políticos ou às exações religiosas. Para saber mais sobre isso, foi preciso, em primeiro lugar, que alguém desse crédito a uma palavra de mulher, considerada pouco digna de confiança, ao contrário da do homem, supostamente direita (essa palavra, bastante evocadora, mereceria ser explorada de modo mais amplo). Ela quase não teria tido chance de se fazer ouvir por um representante de um dos grandes discursos, político ou jurídico, filosófico ou teológico, que, aparentemente, no final do século passado, tinham ainda suas amarras sólidas na sua tradição metafísica. A medicina não estava melhor preparada para receber essa palavra insensata, ainda que estivesse se transformando da cabeça aos pés, graças à cientificidade nova de seus métodos de investigação que ganhou um impulso excepcional e durável graças aos trabal hos de Helmholtz e de Dubois-Reymond, em Berlim, e de Claude Bernard, em Paris. Foi através de Brücke, representante deles em Viena, que Freud foi introduzido nesse novo paradigma científico que pouco a pouco livrou a medicina de seus pressupostos e preconceitos tradicionais para Ihe conferir, em compensação, um brilho e um prestígio jamais atingidos. Não é de se surpreender que esse filho de imigrantes em busca de reconhecimento tenha desejado tornar-se, por sua vez, mestre de uma disciplina ornada com tal auréola.

A Traumdeutung nos relata algo de suas esperanças e de suas decepções, os obstáculos que encontrou seu W unsch de tornar-se professor, as dificuldades com as quais se deparou como judeu. Esse livro inaugural da psicanálise Ihe permitiu fazer não apenas o luto de seu pai, como ele próprio escreveu no prefácio à segunda edição (1908), mas, também, se inscrever na transmissão universitária dessa medicina tão cobiçada e em transformação. Desse fracasso ab initio de seu iniciador e fundador, a psicanálise carrega, até hoje, as seqüelas e a marca indelével que causa, a um só tempo, sua fragilidade e sua força. Ela foi condenada, desde o início, a se situar nas margens e nos interstícios das instituições existentes e em relação às lacunas dos discursos estabelecidos. Não era essa a posição das mulheres, desde sempre, desde o tempo, ao menos, de que é possível se lembrar? Sobre isso, no entanto, não é inútil assinalar um mal-entendido tenaz que acompanhou essa nova discursividade desde seus primeiros passos: a psicanálise nunca fez suaa "causa das mulheres"; o que explica uma relação antes conflitante com o feminismo, sobretudo em sua variante militante, que comumente rejeita Freud e o freudismo concedendo ao mesmo tempo, ao menos provisoriamente, um certo crédito a Lacan e à sua teoria da sexualidade feminina. 
Mesmo se o "primeiro" psicanalista não se livrou de todas as premissas da metafísica - Alexandre Koyré (1957) dizia, com bastante humor, mais ou menos a mesma coisa de Copérnico - reconheçamos sua coragem extraordinária de ter sabido estar na ponta da subjetividade de sua época, aventurando-se para além dos limites, impostos pela tradição, entre os diferentes campos do saber que seus representantes defendiam como uma aquisição que Ihes caberia de direito. Freud não se apropriou da histeria como de um território a ser conquistado, mas a abordou, antes, como um discurso a ser descoberto e estudado. Deixando-se ensinar por essa palavra incômoda e inaudita, inqualificável e inclassificável, quando não no modo do opróbrio ou da exclusão, ele pôde achar aí a fonte de inspiração para a elaboração de uma nova discursividade. Esta, entretanto, não se impôs de uma só vez e Freud é, apesar de tudo poderia ter sido de outro modo? - um filho de seu tempo. Os abalos econômico e social que se produziram ao longo do século passado, em prol da industrialização e da colonização, foram apenas meros precursores das catástrofes políticas e humanas de uma ordem bem diferente que marcou esse século, que viu surgir mestres bem mais ferozes que os antigos. Uma análise sumária veria aí como um último sobressalto dos traços mais virulentos e mais destruidores de uma virilidade, já abalada e atingida em seu status, cuja desmesura só era igual à sua fragilidade. "A mulher", quanto a ela, seria mais pacífica??

Canetti (1960) tinha razão de atribuir à paranóia uma dimensão política, como ele expõe na última parte de sua obra princeps referindo-se particularmente ao "caso Schreber": "Encontraremos em Schreber um sistema político que nos parece ser terrivelmente familiar." ("M an wird ein politisches System bei Schreber finden, das einen unheimlich vertraut anmutet", p. 198). Ao mesmo tempo que menciona seu projeto delirante de se transformar em mulher, ele refuta, categoricamente, a tese freudiana da paranóia como defesa contra a homossexualidade: "Não é possível cometer um erro maior" ("Ein grösserer Irrtum ist kaum möglich", p. 506). 0 interesse para nós das "Memórias de um nevropata" (SCHREBER, 1903) é que o sistema que elas expõem realiza no plano do delírio aquilo a que a histeria acede em outro registro, o da fantasia, a saber, a submissão à posição feminina, contra a qual ele, de início, tanto se defendeu, fazendoa sua. Alguns perversos, para chegar ao mesmo resultado, são obrigados a colocála em ato no real de seu cenário. 0 discurso ambiente lhes é favorável atualmente e conduziu o legislador, em alguns países, a tomar medidas que visam proteger sua posição e até mesmo dar-Ihe um estatuto próprio, o que há bem pouco tempo teria sido literalmente impensável. Por todos esses motivos, é sobre as perversões e o que elas implicam que as questões teóricas e discursivas parecem ser as

\footnotetext{
2 É o que Margarete Mitscherlich parece supor, in Diefridfertige Frau (A mulher pacífica).
} 
mais importantes no futuro, como foi o caso para a histeria há um século, e para as psicoses, desde os anos 1950.

Os freudianos são pegos de surpresa por uma modernidade, que eles contribuíram para modelar, e por uma feminilidade, que até então não tinha ousado se dizer e se mostrar, que estavam, no entanto, entre os primeiros a pôr em evidência; eles tinham até mesmo lhe reconhecido um lugar de destaque colocando-a no centro de seu projeto clínico e terapêutico. Eles se sentem ultrapassados ao ver exposto à luz do dia aquilo que para eles constituía um dos núcleos do recalque e se interrogam, alguns ao menos, sobre sua parte de responsabilidade nesse "retorno do recalcado", surpresos, às vezes abalados, por encontrar na primeira esquina a bissexualidade, cujo caminho eles tiveram de abrir com amargas lutas teóricas e que correspondia a suas hipóteses mais ousadas. Tratar-se-ia do disfarce/ desvelamento mais recente e mais provocador da histeria jamais domada? Eles se encontram, às vezes apesar deles, no lugar do filho mais velho ou do ancestral, que, de certa maneira, eles sempre ocuparam e até mesmo reivindicaram, para assistir, impotentes, a efeitos de seu ensinamentos que eles não tinham nem previsto, nem desejado, ao menos nessa forma. Não há dúvida alguma de que uma certa modernidade se inscreve, abertamente, no avesso de seu discurso, reivindicando-a implicitamente até nos menores detalhes. Esta relação complexa não deveria Ihes causar medo, já que ela constitui uma chance e uma espécie de desafio que Ihes cabe indicar, talvez um "convite à viagem", que pode lhes permitir fazer novas descobertas. No entanto, eles nada têm a esperar de um puro debate das idéias, mas deveriam voltar ao que constituiu seu ponto de partida, a saber, o estudo e a pesquisa clínicos, verdadeiras marcas de sua originalidade.

A clínica psicanalítica se definiu, como indicado, segundo um leque mais ou menos amplo das modalidades de defesa contra a posição feminina e o que ela veicula e implica, quer dizer, uma diferença radical que associamos com a castração. Este último termo é um dos mais debatidos e dos mais controvertidos tanto pelos freudianos quanto por seus adversários. A seguir, vou tentar, a partir de uma nota clínica, dar minha contribuição a esse dossiê já bem extenso. Será minha maneira de homenagear essa formidável abertura discursiva induzida e introduzida pelos "Estudos sobre a histeria", publicados há exatamente um século. Essa abertura atraiu para a psicanálise grandes homens e mulheres, mas também teve como efeito repelir outros que em vez de consistência e univocidade só encontraram metáfora escorrendo entre os dedos, como areia, escapando assim a seu esforço de domínio ou de "apreensão" (no sentido de concipere, begreifen).

Esse novo discurso não é, no entanto, desprovido de conceitos, mas está, talvez, sempre em busca de seu estatuto. São significantes que, sem ser fixos, se 
inscrevem de maneira particular no tempo e continuam a significar fora do contexto de sua emergência, ao qual, todavia, é indispensável poder levá-los de volta, em última instância. Eles contribuem para determinar a especificidade de um dado campo, assim como seus limites, estabelecendo pontes com outros domínios do saber. No que toca a psicanálise, tal função só Ihes cabe em sua relação privilegiada com a castração, que designa um lugar vazio situado no centro de um dispositivo terminológico. É como se a posição feminina, que entrou desde 0 início na textura desse discurso que ela contribuiu para tecer, mais se aproximasse dele. Daí resultou uma dificuldade própria ao discurso freudiano, que foi a de tematizar o que se encontrava em sua origem. 0 que se deixou "apreender" com mais facilidade é o que chamamos de histeria, tanto a do homem quanto a da mulher. Não é o menor motivo para se interessar por ela e estudá-la, não esquecendo que ela é, de início, definida como mecanismo de defesa contra a posição feminina. Não está excluído, entretanto, que tal aporia, que foi pouco evidenciada, possa conduzir a um impasse teórico.

\section{INSCRIÇÃOE RELAÇÃODOS SEXOS}

Vamos dar agora a palavra a essa jovem analisante no início dos trinta anos e mãe de uma menina cujas palavras aparentemente contraditórias refletem bem o paradoxo da posição feminina no que concerne à relação dos sexos. Ela diz, a um só tempo, que nunca teve orgasmo e que acaba de ter uma maravilhosa noite de amor, que ela é fria e insaciável, que Ihe acontece ficar frustrada e satisfeita com 0 ato sexual. Ela acrescenta que descobriu sua sexualidade tardiamente, que esperou até seus vinte e dois anos, idade de suas primeiras relações, antes de "se tocar" e que suas tímidas tentativas de se masturbar pouco lhe deram prazer. Em seu idioma, para falar de seu sexo, ela utiliza um significante que se aproxima do alemão Scheide, vulva, termo de uma grande riqueza, que poderia por si só constituir, com o que ele evoca ou implica, o ponto de partida e o suporte de todo um desenvolvimento sobre a sexualidade, em particular a feminina. ${ }^{3}$ Scheide quer dizer, com efeito, estojo, bainha, capa, mas também fenda e sobretudo limite, fronteira, separação. 0 campo semântico coberto por esse termo designa os cortes essenciais que escandem a vida do sujeito e se estende até suas extremidades. Eis dois exemplos disso: de verscheiden, morrer, só a forma do particípio, com valor adjetivo, verschieden, tem uso corrente e significa, a um só tempo, diferente e morte; unterscheiden, diferenciar, permite nomear as diferenças dos sexos e das gerações, portanto os fundamentos do simbólico;

\footnotetext{
${ }^{3}$ Acrescentemos ainda, no rastro do que precede, que de Scheide é também derivado Scheit, pedaço de lenha cortada, que deu lugar, no século XVI, ao termo de Scheiterhaufen, fogueira. É como se o gênio da língua tivesse estabelecido uma relação entre a fogueira e o sexo da mulher.
} 
nesse contexto se situa, igualmente, a significação jurídica de Scheidung, divórcio. Esse lugar de onde toda vida emana seria também aquele onde ela vem fracassar? É, provavelmente, o receio de muitos neuróticos e também o que poderíamos ouvir nessa exclamação do Coro, em "Édipo em Colônia", Iamentando-se sobre o herói trágico esgotado e em fim de linha: "Não nascer (mè phunai), eis o que vale mais que tudo. $\mathrm{Ou}$ ainda, vindo à luz, voltar de onde se veio, o mais rápido possível, é a sina a ser colocada logo depois." (SÓFOCLES, p.129).

\section{ONOME INDIFERENCIADO}

A analisante demorou para avaliar a que a expunham a descoberta e a consideração de seu sexo, esse ponto de partida de todas as espécies de diferenças e de distinções que, até então, ela havia tentado evitar com todo o cuidado, mas sobre as quais ela devia se render à evidência, repousa o "mundo". Pouco a pouco ela se abriu para a amplitude do questionamento que daí resulta. Ela achava sua situação impossível e inaceitável; ela a tinha, no entanto, escolhido e desejado, até em seus menores detal hes. Ligava-se ao pai de sua filha, com mais ou menos dois anos no início do tratamento, por uma relação física muito forte, mas igualmente efêmera. Ela sabia, pertinentemente, que esse homem, que já tinha um filho quase adulto e que havia deixado a mulher há anos, não procurava de modo algum uma ligação estável e durável; isso contribuiu, com certeza, para tornar as coisas possíveis para ela. Ela havia chegado, além disso, ao fim de uma longa relação com um homem com quem ela acabava de construir uma casa pronta para ser habitada. Quando ficou grávida, já que não tinha tomado a precaução de se proteger durante as relações, ela deixou o amante, sem Ihe dar a menor explicação. Ele também não pedira, mas não havia desaparecido completamente de sua vida; ela continuava, entretanto, escondendo dele que ele era o pai de uma menina. Também não revelou a menina a identidade do pai. Contudo, a questão a havia preocupado o bastante para que ela decidisse vir me consultar.

Enquanto ela tinha vivido sozinha e levado uma vida independente, logo nos primeiros meses de gravidez, ela voltou a viver com os pais, "junto a meu pai", dizia ela, sob um mesmo teto, embora em um apartamento diferente. Ela se deu conta bem rapidamente, desde as entrevistas preliminares, de que estava realizando uma fantasia muito antiga, a de viver sob um mesmo teto com seu pai e sua filha, a quem ela havia transmitido seu sobrenome paterno. Assim, ela manteve e cultivou a ambigüidade, consciente e inconsciente, de que seu pai poderia também ser o pai de sua filha. Foi graças à sua gravidez que ela reatou com um passado onde seu pai ocupava o primeiro plano da cena da transmissão, sobre a qual sua mãe, muito presente, aliás, só aparecia em um segundo papel, e até mesmo como uma mera figurante. 
Essa utilização do nome, com várias variantes possíveis, é bastante freqüente hoje e parece, portanto, ser relativamente anódina. Não deixa de ser um abuso, e em certas condições uma usurpação do nome, com conseqüências imprevisíveis para a geração ou as gerações vindouras. É óbvio que é melhor para uma criança ter o nome de seu pai, a fim de ser inscrito em um lugar diferente do discurso materno, do qual será mais fácil para ela se separar em seguida. Se a criança tem o nome de solteira de sua mãe, é como se esta tivesse ficado grávida do nome de seu próprio pai, que, em todo caso, ocupa o lugar daquele de onde a transmissão procede. A fantasia, de modo quase obrigatório, se apodera dessa constelação, que é a do incesto. 0 resultado pode ser uma indiferenciação dos nomes e uma confusão dos lugares. A coabitação aqui é um fator de complicação suplementar. A criança, cedo ou tarde, será confrontada com a questão: quem é quem? (who is who?). Foi o que aconteceu com essa outra analisante, antiga anoréxica, que durante muito tempo ficou profundamente fixada no discurso parental. Com vinte anos apenas, ela teve uma filha de um jovem psicótico, que encontrou... no consultório de um terapeuta precedente, tendo continuado a viver na casa dos pais e de sua avó materna. Seu pai, quase todos os dias, ia visitar sua própria mãe que morava perto dali . A analisante obstinouse, com êxito, em evitar qualquer contato e, portanto, a tornar impossível qualquer relação com o pai de seu filho. Quando, no final de um certo percurso analítico, ela deixou a casa da família, escolheu, de início, um apartamento, a dois passos de sua casa e que pertencia a seus pais. Em seguida começou a viver com um homem um pouco mais velho, que veio morar em sua casa com 0 filho, um jovem adolescente. Essa nova constelação acarretou mudanças notáveis, sobretudo em relação aos lugares ocupados por cada um dos protagonistas. A jovem mãe ficou siderada ao ouvir sua filha dizer, depois de um certo tempo de vida comum: "Um papai não é, então, um vovô." Ela teve que se render à evidência de que até então sua filha, que tem seu nome de solteira, havia vivido na confusão, alimentada por ela, desses dois lugares e papéis pertencentes a duas gerações diferentes.

Esses dois exemplos salientam o papel da casa como representando a família e a filiação. É também o caso nas principais línguas faladas no 0 cidente, assim para domus, em latim, oikia ( ou oikos), em grego, beit, em hebreu. O Talmude fala de beit Hillel e beit Shammaï, as casas de estudo de dois grandes mestres da Michna que são representativas de duas leituras diferentes da lei, e portanto da tradição. O hebreu oferece ainda outras possibilidades associativas, pois beit é também a segunda letra do alfabeto e a primeira da Thora (Berechit..., No começo...) : foi pela letra beit que o mundo foi criado. Ela é escrita conforme uma curva pronunciada, significativa, que evoca a que desenha a barriga de uma mulher grávida: a letra beit $ح$ é a escritura da 
primeira morada e como tal representa a morada simplesmente, a do sujeito, em sua relação fundamental, mas não exclusiva, com o feminino e com o materno. Eis por que a tradição diz que a mulher é o baitt (a casa) do homem; isso deve ser considerado em toda abordagem do lugar da mulher na transmissão. Ora, a clínica nos ensina que a escritura não simboliza nada. 0 analisante que anota seus sonhos, no mais das vezes, não faz mais que consolidar sua resistência e sua oposição a que eles possam ser interpretados. A simples transcrição em uma linha familiar não basta para dar acesso à metáfora (paterna), que é a única em condições de ratificar, de validar retroativamente (nachträglich) essa "escritura primeira". Isso nos sugere que a escritura interviria antes do lado da mãe e sua interpretação antes do lado do pai; o que permitiria compreender melhor certos percursos de escritor. Dizendo de maneira mais imagética, no contexto dessa digressão sobre a letra, desenhar a curva da barriga ou a da gravidez é apenas o ponto zero de uma seqüência temporal muito precisa, 0 prelúdio a uma sucessão de acontecimentos tão significativos, que eles são tão metafóricos quanto reais: a abertura da fenda e a ruptura das águas, expulsão, corte do cordão e primeiro grito, abertura das membranas alveolares e passagem do ar, evacuação da placenta, nomeação em seguida e inscrição em um registro (do estado civil). É como uma porta que se abre para outra porta que se abre para outra ainda, etc.

A analisante, para voltar a nosso exemplo clínico, soube evitar um certo número de aberturas e de cortes, em sua relação com o corpo e a sexualidade, ao querer manter, até mesmo reinstituir na idade adulta, a constelação de sua sexualidade infantil, para nela inscrever sua filha. Esta tentativa de remontar 0 fio do tempo corroborava sua recusa das responsabilidades, que ela deixava a cargo dos homens, de seu pai, a princípio. "Eu queria encenar a menina que teve uma infância tão infeliz e que teve tantos desgostos." Ela queria que os homens pagassem o que seu pai Ihe teria feito "sofrer", mas tentava, talvez, sobretudo, com esse estratagema, mantê-lo no lugar e fazer os outros homens aparecerem em sua insuficiência. Evitando assim o corte desse laço primordial e portanto a perda do amor do pai, ela instalava sua vida amorosa em uma desordem bastante considerável que começava a inquietá-la. Salvaguardando um objeto fora de seu alcance, inacessível, ela tentava estabelecer um desejo de outra coisa diferente de tudo o que o cotidiano podia Ihe oferecer. Acontecia o mesmo em sua relação com o gozo: manter o gozo de um pai mítico (aquele da fantasia), a custo de sua frigidez, era também uma maneira de dizer aos homens que eles não estavam à altura, que eram incapazes de lhe dar "isso". 0 papel da mulhercriança, que ela adotava de bom grado, Ihe permitiu opor-se, de modo mais ou menos eficaz, aos efeitos do tempo e portanto do luto. Ao mesmo tempo que tinha uma vida sexual bem movimentada, sendo mãe de uma menina, era como 
se ela fosse animada por uma obstinação ferrenha de sobretudo não se abrir para outrem, para o tempo e para si mesma.

Foi para salvar um laço ancestral que ela se entregou a esse perigoso exercício de escritura, o de inscrever o nome de seu próprio pai para sua filha. Sua sintomatologia, antes de tudo sexual, encontrou aí um ponto de apoio sólido. A prática analítica, por sua vez, fica suspensa nessa escritura, prelúdio de todas as outras, do nome próprio, cuja lógica - outra modalidade da escritura - da incidência na vida do sujeito ela evidencia, juntando a ela, todavia, uma dimensão oral suplementar. Ela acrescenta ao texto o que não se encontra nele, para introduzir aí uma abertura para uma coisa diferente dele próprio - é o que chamamos de interpretação. Este acréscimo, precedido, no mais das vezes, do sinal da negação, permite ouvir de outro modo o que está escrito, de ler, em particular, o nome de modo diferente do que está escrito. É unicamente com essa condição que intervém e que se transmite o nome do pai, como instância simbólica e em sua diferença com o sobrenome paterno. Desse ponto de vista, a psicanálise tem uma grande dívida com a tradição judaica, que ela está longe de ter reconhecido.

A analisante não desconhecia o que estava se passando. É como se ela tivesse parado à beira de um processo, para barrar a metáfora paterna. Ela afastou o pai de sua filha de linha familiar potencial, evitando ser tocada no fundo de si mesma, amorosa e sexualmente. Ela não dizia nada além disso ao evocar sua frigidez, que andava junto com o desejo sexual insaciável. Ela devia por isso permanecer intocável e deixar nesse estado uma parte importante de seu passado, a fim de subtraí-lo aos estragos do tempo. Nisso repousava, antes de tudo, esse desejo imortal (der unsterblicheW unsch) "da" criança (FREUD, 1900/ 1941, p. 559), formulação cujo duplo sentido do genitivo sugere essa versão muito difundida da fantasia da histérica, ter um filho do pai - sem ser tocada. Tal paradoxo está ligado à estrutura da fantasia, cuja função é preservar para além das rugas da idade, da maternidade também, um lugar que deve ficar vazio, "virgem" de certa maneira, a fim de manter viva a economia libidinal do sujeito. A virgindade seria entendida, então, como um fator temporal que introduz uma cesura indispensável ao acionar do desejo. A idéia de ter podido ser "tocada", mesmo que só por alusão ou de maneira indireta, é tanto mais insuportável para o sujeito que chegou à idade adulta, quanto ele sente esse lugar ameaçado. Isso pode dar lugar a longos percursos analíticos, a fim de esvaziar esse lugar de um gozo que aí havia ou teria feito irrupção, e às vezes também a processos de ressonância, a fim de restabelecer uma lei que foi abertamente achincal hada.

Não é desinteressante acrescentar nesse contexto que intocável é também um termo jurídico que se aplica àquele que não se enquadra na lei e não pode, 
portanto, ser objeto de sanção alguma ou, em outro registro, àquele que é excluído da sociedade (como o paria, na Índia) e portanto não se beneficia da proteção da lei. No plano religioso, a mesma noção serve para designar, particularmente, o que corresponde aos diferentes graus de impureza concernente, entre outros, às feridas do corpo (que podem conduzir até a exclusão da sociedade, no caso da lepra), os corrimentos do corpo (que travam as relações sexuais, e até mesmo as proíbem) e, último estágio, o cadáver (ou seja, o corpo subtraído às leis da vida e de sua reprodução). Isso nos dá uma idéia da extensão do campo semântico coberto por esse termo, do qual só extraímos uma parte, suficiente, entretanto, para nos dar uma idéia do que está em jogo para o sujeito em sua relação com o inconsciente e com a lei.

A analisante nos ensina, à sua maneira, ou seja, a contrario, que a posição feminina se define por um certo número de aberturas, que ela consegue introduzir nos diferentes registros do sexual: o genital, o materno e o filial. São relações ao corpo que se inscrevem em uma seqüência temporal bem precisa, que uma mulher dispõe preferencialmente - ela tira daí sua força, mas se arrisca também a ver seu arrebatamento interrompido - , e à qual um homem, por sua vez, deve se submeter, se ele quiser intervir no processo da transmissão. As aberturas em questão, no entanto, só se sustentam em sua multiplicidade com referência ao que as mantém juntas, a saber a meáfora paterna. Ela opõe 0 único limite válido ao real do gozo, bem como em outro plano ela é responsável pela transformação da imagem do corpo pela gravidez e pela inscrição da criança que vai nascer no simbólico. Ela é esse fio invisível que liga entre si os diferentes domínios da vida do sujeito, Ihe permitindo se encontrar neles e reconhecer a unidade de sua ação na diversidade de seus atos, que ele sempre dá um jeito, se for neurótico, de fazer com que fracassem. É o resgate de sua "liberdade" que ele adquire a custo de sua alienação, ou seja, de ser, no essencial, estranho a si mesmo. Sua única chance de aceder a ela é a de se submeter ao que o determina no lugar do Outro, reconhecendo a causa de seu desejo, como uma "causa ( coisa) perdida", desde sempre.

Onde estava nossa analisante em relação a seu desejo? Ela nos dá uma idéia dos obstáculos, às vezes difíceis de ser superados, que a metáfora paterna pode encontrar. Ela queria ser mulher rejeitando, ao mesmo tempo, com veemência, o que poderia tê-la conduzido a isso, pela simples razão que nenhum homem era capaz de torná-la mulher "absolutamente". Ela devia, portanto, logicamente, recusar a abertura que ele Ihe propunha, que teria significado o abandono de sua "pretensão ao título" (de mulher, de rainha). Renunciar a isso, para se submeter a nada de tangível seria lhe pedir demais. Isso se manifestava em sua fantasia amplamente desenvolvida de que um homem se arrastasse diante dela para implorar seu perdão por todo dano que ele teria Ihe causado. Essa ficção, 
que impunha seu colorido à sua vida sexual, tinha por conseqüência o fato de ela só poder aceitar como parceiro alguém que renunciasse a ser verdadeiramente homem. 0 que ela chamava de "frigidez" era um compromisso, afinal de contas bem cômodo, entre as diferentes tendências que a habitavam e que the permitiam preservar aquilo a que ela não estava pronta para renunciar, uma certa relação com o poder e com o gozo, cujos gostos se confundiam.

Para caracterizar uma relação física muito forte, ela chamava de "paixão" ou mais facilmente ainda de "transe", evocando um estado próximo da experiência mística, que Lacan tentou aproximar daquilo que seria o próprio do gozo feminino. Não é especificado que parte do corpo entra em jogo no estado de transe, se não for o corpo inteiro, cujo despedaçamento imaginário com referência a uma instância simbólica (fálica) ficaria assim suspenso, provisoriamente. Isso não impede o sintoma histérico, dito de "conversão", de se estabelecer, em último caso, segundo as linhas de fratura de um corpo, que não é, justamente, 0 da anatomia.

Jogando com as palavras, poderíamos acrescentar que houve trans-, mas não -missão. A analisante queria, em todo caso, impor sua própria lei à transmissão. Ela queria ser mãe, mas sem aceitar para seu filho a mínima lealdade para com um homem, a submissão, portanto, ao que só um homem pode veicular: essa instância simbólica que determina a identidade sexual e a inscrição nas gerações. 0 único que a seus olhos teria podido desempenhar esse papel era seu pai, que, entretanto, não era o melhor colocado para fazê-lo. É como se ela tivesse querido conceber um filho, segundo a ordem da fantasia, e com isso mesmo se alçar ao nível da geração de seu pai. Ela tinha, no entanto, total consciência das dificuldades que estava criando e às quais expunha a filha.

Ela se perguntava também se o que estava Ihe acontecendo não era uma maneira de reagir ao que ela havia percebido do lado de sua própria mãe, concernente a seu lugar na família. Ela estava praticamente ausente em seu discurso, mas não menos presente no real de sua vida; é como se essas duas dimensões tivessem dificuldade de se agenciar. Ela me dizia: "Minha mãe é como a sombra de meu pai." Tal formulação sugere, em todo caso, que sua posição de mãe era igualmente apagada e inapagável, inexistente e, no entanto, onipresente. "Como se livrar de uma sombra?" poderia ter sido a questão de sua filha que estava frustrada com uma rivalidade com uma mãe que tinha encontrado um meio bem eficaz para se proteger dela. Isso explica o impacto de uma referência paterna por demais exclusiva e diz muito dos receios da analisante em relação com sua própria maternidade, ligada, imaginariamente, a uma ameaça para sua autonomia, sua própria existência. É como se ela tivesse querido salvar sua pele recusando a um homem tomar o lugar de pai de seu filho. É verdade também que o genitor não queria saber de nada disso, mesmo quando foi infor- 
mado, anos mais tarde. Soubemos depois que o avô materno era alcoólatra (ou tinha assumido esse papel), razão pela qual os avós paternos teriam se oposto a esse casamento. Por não ter sido rejeitada, sua mãe teria dado provas de uma gratidão excessiva. Seu próprio apagamento, entretanto, não adiantou de nada para ela, nem para sua filha. Ela só fez Ihe deixar uma culpa inarticulada, quase em estado bruto, tal como, provavelmente, ela havia recebido de seu próprio pai. Tal culpa, que a analisante tinha em parte endossado e que estava passando para sua filha, permanecia sob a autoridade de um super-eu feroz e era acompanhada de uma relação com o gozo mais destruidora pelo fato de não estar pronta para renunciar a ela. Isso intervinha, provavel mente, para determinar sua relação com a sexualidade, a atitude de submissão adotada por sua mãe, assim como o alcoolismo de seu avô.

O super-eu intervém aqui, de modo bastante freudiano, na herança (Vererbung) de uma culpabilidade que impõe seu colorido ao sintoma sobre várias gerações. Ele se opõe de modo mais ou menos eficaz à transmissão do nome-do-pai, tendo como conseqüência uma perturbação bastante considerável da relação com o gozo, como o ilustra bem esse exemplo clínico. 0 percurso analítico consiste em "transferir" a culpa para outro plano, em outro registro, a fim de traduzi-la e transformála em dívida simbólica. Para conseguir isso, convém levar em conta três gerações que intervêm no Édipo. Seu desenlace pode ser comparado com a interpretação de um texto que se deixa "abrir" e despojar de um sentido dado, para dar lugar a traduções sucessivas. A criança que vai nascer torna-se 0 vetor de uma nova versão de um texto, cujo original está perdido. 0 verdadeiro "dom" da vida corresponde a deixar advir uma criança a seu próprio mundo simbólico e, portanto, para uma mãe e também para um pai, a não fazer obstrução a que ela tenha seu nome de modo diferente do que ela o recebeu.

\section{FLEXÃODONOME}

O que nos ensina essa história clínica, da qual só forneci poucos elementos, sobre a questão tão importante, que nos ocupa aqui, da função simbólica de uma mãe? Deve-se observar que sobre isso a literatura psicanalítica ficou relativamente em silêncio, com algumas exceções, quando as publicações sobre o feminino e o materno estão cada vez mais numerosas. Só encontramos poucas indicações sobre o que é, no entanto, essencial, a saber, como uma mulher se inscreve, diferentemente de um homem, em sua relação com as gerações. A razão disso é, e esta é a minha hipótese, que o tema da transmissão foi pouco abordado como tal, mesmo se, de maneira implícita, ele está presente desde os primeiros passos do discurso freudiano.

Isso nos permite retomar nossas observações iniciais: se a historiografia tradicional, como afirmam dois grandes especialistas, teve tanta dificuldade em 
coletar os vestígios da feminilidade no passado, é que o modo de escritura que lhe é próprio se encontra menos nos livros do que no livro - da vida. Talvez fosse preciso ser mais radical e dizer que os vestígios não são historiáveis, não são da ordem da história, mas se inscrevem em outra relação com o tempo. Isso não significa que as mulheres não escrevem belos livros, mas, em regra geral, elas os escrevem de outro modo, a não ser que seja com um objetivo de reconhecimento universitário ou outro. A diferença fica, por exemplo, bem clara no nível das intrigas policiais, para as quais elas têm infinitamente mais tal ento do que a maioria dos homens, autores de livros policiais. Não é surpreendente para aquele que sabe reconhecer, com seu valor justo, a qualidade intrínseca de certas grandes intrigantes. Se a tecelagem é reconhecida como sendo uma das ocupações femininas mais antigas, nas tradições que chegaram até nós, é porque, em todos os tempos, as mulheres constituíram a textura da vida. Tampouco alguém colocará em dúvida seu lugar central na coesão do tecido social, do qual ao menos um dos aspectos é imediatamente apreensível e conhecido de todos: o que se chama, de maneira pejorativa, de "fofoca". É apenas uma corrente de uma função essencial, que não deveria ser subestimada, pois sem ela a vida social ficaria sem alma. Ela se manifesta às vezes, é verdade, na forma destrutiva da "má língua", mas cujo monopólio as mulheres estão longe de ter.

Para uma mãe, é tão difícil quanto para um pai aceder à sua função simbólica. Ela deve, para tanto, traduzir a palavra deste para seu filho, para cada um de modo diferente, discuti-la e até mesmo, se ela for injusta, defender outro ponto de vista. 0 sentimento de justiça que habita cada criança, a anima e a preocupa no mais alto grau, nutre-se nesta fonte. Ele se refere, às vezes por toda uma vida, a situações do mesmo tipo, ao que foi dito realmente e à maneira como isso foi retomado, divulgado, transformado. A criança fica ainda mais ofuscada, ferida, perturbada quando a palavra, que deve supostamente veicular a lei, foi mal traduzida. Na gênese de uma psicose intervém, no mais das vezes, o sentimento de ter sido manipulado por uma mãe, que se põe acima da lei ou cujo discurso só contém referência à autoridade paterna para humilhá-la. Não menos freqüente é outro fracasso da função materna que consiste na incapacidade de introduzir uma abertura em um discurso paterno por demais compacto ou autoritário e portanto intraduzível. Eis por que certos psicóticos, tornados adultos, passam sua vida pedindo justiça diante dos tribunais, por causas consideradas, com razão, loucas. Eles não desconhecem isso, no mais das vezes, porém é o último recurso que lhes resta para fazer intervir uma terceira instância e a fim de evitar um colapso do simbólico. Isso caracteriza o percurso de um bom número de paranóicos, em particular aqueles que são chamados de "querelantes processivos". Na vertente da esquizofrenia, não é raro assistir a um modo de entrada na psicose através de uma passagem extrema ao ato, às vezes homicida. 
É ainda uma maneira, desesperada e um tanto paradoxal, de fazer intervir um terceiro que cruelmente faltou. Seria fácil dar outros exemplos desse apelo à justiça, que existe tanto no grande criminoso quanto no extremista político ou religioso, como também pode se encontrar na base de engajamentos muito mais moderados ou dar lugar, por que não, a uma elaboração teórica da justiça social. Tal aspiração, tão profunda, existe porque ela visa o que está na origem do simbólico e de sua amarra subjetiva. Tudo parece ser uma questão de justa medida, de justa apreciação das coisas e dos limites.

A analisante se encontrava em uma constelação edipiana particular que lhe causou muitos problemas, mas que ela ainda não estava pronta para resolver. Ao tornar-se mãe, por sua vez, ela teria podido decidir fundar seu próprio lar, quando escolheu, ao contrário, voltar para aquele de onde era oriunda; por comodidade, dizia ela, mas havia, provavelmente, outra coisa. Isso constituía uma hipoteca pesada, que, entretanto, nada tinha de definitivo, em relação à abertura que ela teria podido contribuir para produzir em uma linha familiar. Esta fica suspensa na inscrição do recém-nascido em um registro, a fim de que ele possa ser chamado por um sobrenome e um nome; mas ela só tem uma chance de prosseguir, de atravessar o tempo se a cada geração se produz uma abertura bem específica, inédita, que permite a uma criança achar seu lugar, gra ças a uma versão do nome que Ihe é própria. Será seu tesouro mais caro, sua vida inteira, ao qual ela não poderá renunciar, mesmo sob ameaça de morte. A metáfora, ligada de maneira indissociável ao que é novo, é o único escudo eficaz contra a pulsão de morte e dá ao sujeito os recursos simbólicos necessários que Ihe permitem se separar do automatismo da repetição (W iederhol ungszwang). Ora, a abertura em questão está ligada à posição feminina, determinada no essencial, mas não exclusivamente, por sua relação com a castração simbólica, operador essencial da inscrição do sujeito na lei e na linguagem. Inapreensível enquanto tal, a castração se manifesta clinicamente pelo efeito de feminilização que ela acarreta no nível do corpo, independentemente do sexo. 0 homem, com efeito, não escapa dela, mas a feminização ganha um colorido bem diferente segundo sua estrutura: o que contribui para Ihe dar um status simbólico como histérico e que o perverso terá tendência a revestir, imaginariamente, para eventualmente exibi-lo à luz do dia, o paranóico o perceberá como a maior ameaça, de tornarse mulher realmente.

Schreber passou por isso e tentou encontrar uma saída, na lógica de seu delírio. Depois de uma rejeição inicial categórica, ele aceitou a idéia de uma emasculação e portanto de uma feminização ao menos potencial, ou seja, só se produzindo em um futuro longínquo, hipotético e da qual ele só precisaria se aproximar de maneira assintótica. Ele foi, portanto, obrigado a construir inteiramente uma posição feminina que fez falta de maneira tão cruel em sua infân- 
cia, para fazer contrapeso à estatura esmagadora de seu pai, e no atual de sua vida, para aceder à descendência que sua mulher não Ihe deu. Foi o que fez Freud (1911/ 1941) dizer: "Seu casamento, que ele qualifica de feliz, não lhe deu filhos, em particular, não Ihe deu o filho que o teria consolado da perda de seu pai e de seu irmão, e para o qual ele poderia derramar sua ternura homossexual insatisfeita. Sua linha familiar (Geschlecht) estava ameaçada de extinção, e ele parecia ter sido bastante orgulhoso de sua linhagem (Abstammung) e de sua família" (p.293).Seu delírio Ihe oferecia a saída de um devir-mulher que Ihe teria permitido se deixar engravidar pelos "raios de Deus" e de conceber uma "nova raça de homens" (p. 293). Ele produzia assim sua própria versão daquilo que é o núcleo de toda psicose, a saber, um delírio de filiação. "Schreber pode muito bem ter imaginado que, se ele fosse mulher, ele teria sabido melhor como ter filhos..." (p. 294), ou seja, que ele teria sido uma mulher mel hor para seu pai. Encontrarse na posição de mulher em relação ao pai corresponde à fantasia do histérico (homem ou mulher), que Schreber conseguiu reconstruir no modo delirante.

É interessante notar que Freud, para falar de linha familiar, só cita personagens masculinas: pai, irmão, filho, entre as quais ele admite uma atração homossexual; como se o pai tivesse o poder de transmitir diretamente a seu filho, sem passar pelo intermédio de uma mulher e sem que esta tenha a menor influência sobre o processo. 0 que quer dizer essa observação, a não ser que a atração homossexual no seio da família constitui um cimento entre as gerações podendo impedi-las de se diferenciar e de se inscrever. Uma mulher torna-se cúmplice, se ela realiza assim sua fantasia fundamental, na continuidade de sua própria história familiar e segundo "a ordem" do pai. Foi talvez contra isso que Schreber se defendeu construindo à sua maneira uma posição feminina - e portanto homossexual.

A posição feminina, se ela aceita se submeter à castração simbólica, torna-se um fator de descontinuidade. Ela produz assim uma flexão do nome, na origem de uma abertura ímpar, para dar lugar a outra versão deste. Ele não pode, com efeito, ser transmitido tal e qual, ou seja, igual a ele mesmo. U ma diferença radical ${ }^{4} \mathrm{se}$ acha assim instituída no início de toda vida e funda a amarra subjetiva na lei e no simbólico. 0 significante, por sua vez, se refere a ela, definida como o que não é igual a si mesmo: $A \neq A$. Esse princípio de não-identidade nos ensina, aliás, que a transmissão não poderia se inscrever de maneira exclusiva de um único lado da diferença dos sexos, ${ }^{5}$ mas que ela é sempre e por essência transgressora. Eis por que a nomeação não se produz em linha direta fazendo a

\footnotetext{
${ }^{4}$ Que define a identidade do povo judeu e pela qual ele pagou um tributo elevado.

${ }^{5}$ Foi assim durante muito tempo, para a filosofia e para outros discursos tradicionais. N otemos que é o modo de transmissão de um discurso que determina sua estrutura.
} 
economia da posição feminina, nem pode ser deixada ao único governo desta, mas ela é o efeito de uma inflexão da linha familiar. U ma mulher desempenha um papel privilegiado nesse processo, com a condição de não se identificar com a autoridade que ela contribui para transmitir. Isso é verdade também para 0 homem, de maneira que ambos só encontram seu lugar pelo selo da divisão, que os eleva ao nível de suas funções simbólicas respectivas no sistema de parentesco, como pai e mãe. 0 homem não dispõe mais do nome do que a mulher, mas ele é seu vetor privilegiado - para a criança.

A introdução da questão do nome no raciocínio clínico tem repercussões profundas sobre nossa abordagem e nosso manejo da transferência que se encontra assim subtraída a qualquer apreensão na intersubjetividade. 0 princípio de não-identidade tem um efeito de refração-difração sobre o nome, de maneira que se ele se escreve $\mathrm{N}_{1}$, ele se lê $\mathrm{N}_{2}$, mas só chega à geração seguinte como $\mathrm{N}^{\prime}: \mathrm{N}_{2} / \mathrm{N}_{1} \rightarrow \mathrm{N}^{\prime}$.

$\mathrm{O}$ que se transmite, portanto, não é nem $\mathrm{N}_{1}$, nem $\mathrm{N}_{2}$, e sim a diferença deles. U ma condição necessária é que o nome é recebi do de modo di ferente do que é dado, mas ela é insuficiente. Tal formulação, tributária de uma teoria da comunicação, é incapaz de dar conta do que se passa e se "transfere" entre as gerações. Tampouco bastaria dizer: "mensagem recebida porque recebida na forma inversa". 0 que é válido no plano da intersubjetividade torna-se caduco pela exigências da transmi ssão, cuja fórmula adequada é que o nome é transmitido de modo diferente do que é recebido.

Poder-se-ia imaginar que a pesquisa clínica sobre a histeria e outras estruturas toma o caminho indicado por essa última formulação. Ela deveria também permitir rearticular estas questões tão espinhosas para a prática psicanalítica: como produzir algo novo? E qual é o status do novo?

Recebido em 16/ 4/ 2001. Aceito em 6/ 6/ 2001. 


\section{BIBLOGRAFIA}

BEN NASSAR, B. L'inquisition espagnole, Paris, Hachette, 1979.

CANETTI, E. M asse und M acht, Frankfurt, Fischer TaschenbuchVerlag, 1960/ 1980.

DUBY, G. e PERROT, M. "Écrire I'histoire des femmes", in Histoires des femmes, tomo 1, Paris, 1991.

FREUD, S. Cartas dos dias 17/ 01 e 24/ 01/ 1897, in Briefe anW ilhelm Fliess, Frankfurt, Fischer Verlag, 1986, p. 237-242. . GesameltW erke, Londres, Imago Publishing Co., 1941.

"DieTraumdeutung", 1900, v. II/ III, p. 559.

“Analyse der Phobie eines fünfjährigen Knaben”, v. VII, p. 271.

"Psychoanalytische Bemerkungen über einen autobiographisch beschrieben Fall von Paranoia (Dementia paranoides)", v. VIII, p. 293.

KOYRÉ, A. From theClosedW orld to thel nfiniteU niverse, Baltimore, Johns Hopkins Press, 1957.

LACAN, J. Le Séminaire, Livre XVII, L'envers de la psychanalyse, Paris, Seuil, 1991. MITSCHERLICH, M. Die fridfertige Frau, Frankfurt, Fischer Verlag, 1985. MORELLET, A. Abrégé du Manuel des Inquisiteurs, Grenoble, Jérôme Millon, 1762/ 1990.

SCHREBER, D.-P. Denkwürdigkeiten eines N ervenkranken, Leipzig, Oswald Mutze, 1903.

SÓFOCLES, Oedipeen Cologne, Paris, Les Belles Lettres, 1960.

AndréMichels

53, Rue Bonaparte 75005 Paris 